\title{
Visual Preferences Versus Verbal Preferences
}

\section{Citra Kurniawan}

airakurniawan@gmail.com

Informasi seringkali disajikan dalam bentuk kombinasi antara gambar dan teks. Seseorang memiliki cara tersendiri untuk memproses infomasi yang disajikan, apakah akan mengolah informasi dalam bentuk gambar atau bentuk teks terlebih dahulu (Kurniawan, Setyosari, Kamdi, \& Ulfa, 2018). Penyajian materi dalam bentuk gambar yang diintegrasi dengan teks digunakan sebagai cara untuk menyampaikan pesan yang detail, dimana teks berfungsi sebagai penjelasan atau informasi tambahan dari informasi berupa gambar (Peterson, 2016). Saat informasi yang disajikan semua berupa teks saja maka seseorang berusaha memproses informasi tersebut secara verbalizer semaksimal mungkin meskipun tidak sesuai dengan preferensi yang dimilikinya, semisal seorang visualizer akan berusaha untuk mengarahkan pemahamannya pada perkiraan terbaik dalam bentuk teks (Brunsting, De Best-Waldhober, Brouwer, Riesch, \& Reiner, 2013).

Dalam mempelajari sebuah informasi maka seorang dituntut untuk memahami dengan cepat semua materi yang diberikan. Sebuah informasi dapat diolah dengan baik jika dalam proses pembelajaran, informasi disajikan dalam bentuk yang sesuai dengan gaya belajar yang dimiliki. Sebuah informasi yang diberikan dalam proses pembelajaran dapat dengan mudah dipelajari jika disesuaikan dengan gaya belajar yang dimiliki karena informasi yang diterima diproses dengan cara yang berbeda-beda (Fayombo, 2015). Hal ini sejalan dengan Davis (2007) yang menyatakan bahwa penyajian informasi yang sesuai dengan gaya belajar dapat membuat informasi lebih mudah dipahami dan diingat (Davis, 2007). Oleh sebab itu seseorang diharapkan dapat mengenali gaya belajar yang dimilikinya. Ketika seorang seseorang mengetahui gaya belajarnya maka dapat mengintegrasikan gaya belajarnya dalam proses belajar sehingga dapat melakukan proses pembelajaran dengan mudah, selain itu seseorang dapat menjadi seseorang yang dapat 
memecahkan masalah secara efektif (Gilakjani, Ismail, \& Ahmadi, 2011)seseorang memakai gaya belajar yang dominan dalam proses pembelajaran dan pembelajaran difasilitasi berdasarkan kecocokan gaya belajar dan metode pembelajaran yang diterapkan sehingga saat proses pembelajaran seseorang terbiasa dengan gaya belajar yang dimilikinya (Zarei, Roohani, \& Jafarpour, 2015).

Gaya belajar yang pertama kali diperkenalkan oleh Felder dan Silverman (1988) dan direvisi kembali oleh Felder (2002) mempunyai empat dimensi gaya belajar, Active/Reflective, Sensing/Intuiting, Visual/Verbal, dan Sequential/Global (Wang \& Mendori, 2015). Interpretasi terhadap informasi disajikan menggunakan dimensi Visual/Verbal. Seseorang dengan kecenderungan visual (visualizer) lebih menyukai jika informasi disajikan dalam bentuk diagram, flow chart, gambar sedangkan seseorang dengan kecenderungan verbal (verbalizer) lebih menyukai informasi berupa teks tertulis (Kolekar, Pai, \& Pai, 2017). Visualizer dan verbalizer dipisahkan satu sama lain dengan menggunakan sejumlah alat ukur yang mengukur preferensi belajar sehingga didapatkan hasil pencapaian terhadap proses belajar ketika informasi yang disajikan sesuai dengan gaya belajar yang dimiliki (Awla, 2014). 
IKUTI SAYA (0) el.bejo — by IIRA KURNAWAN -
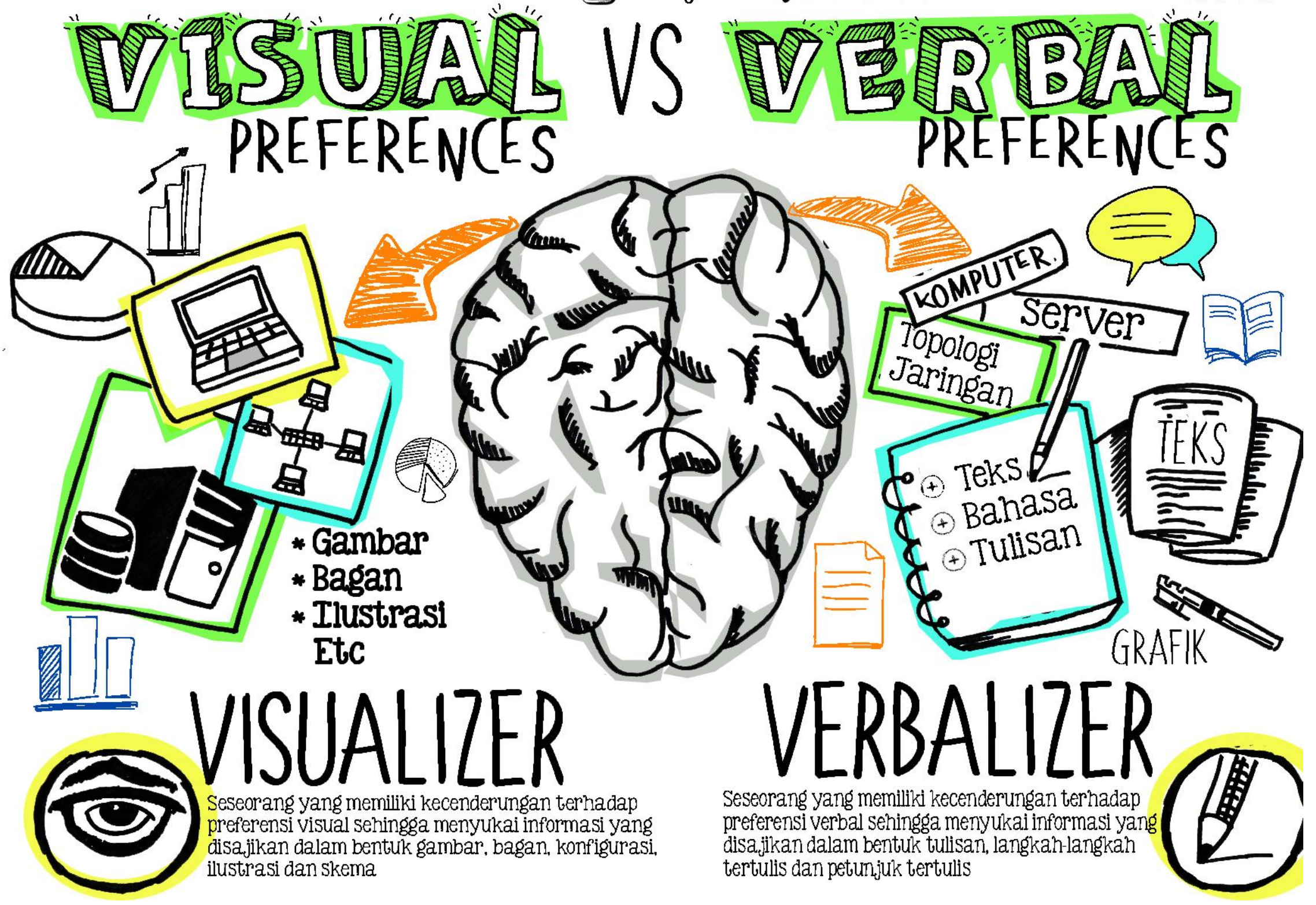


\section{Daftar Pustaka}

Awla, H. A. (2014). Learning styles and their relation to teaching styles. International Journal of Language and Linguistics, 2(3), 241245. https://doi.org/10.11648/j.ijll.20140203.23

Brunsting, S., De Best-Waldhober, M., Brouwer, A. S., Riesch, H., \& Reiner, D. (2013). Communicating CCS: Effects of text-only and text-and-visual depictions of CO2 storage on risk perceptions and attitudes. Energy Procedia, 37(0), 7318-7326.

https://doi.org/10.1016/j.egypro.2013.06.670

Davis, S. E. (2007). Learning Styles and Memory. Institute for Learning Styles Journal, 1, 46-51.

Fayombo, G. (2015). Learning Styles, Teaching Strategies and Academic Achievement among some Psychology Undergraduates in Barbados. Caribbean Educational Research Journal, 3(2), 46-61.

Gilakjani, A. P., Ismail, H. N., \& Ahmadi, S. M. (2011). The Effect of Multimodal Learning Models on Language Teaching and Learning. Theory and Practice in Language Studies, 1(10), 1321-1327. https://doi.org/10.4304/tpls.1.10.1321-1327

Kolekar, S. V, Pai, R. M., \& Pai, M. (2017). Prediction of Learner' s Profile Based on Learning Styles in Adaptive E-learning System. IJET, 12(6), 31-51.

Kurniawan, C., Setyosari, P., Kamdi, W., \& Ulfa, S. (2018). Preferensi Visual-Verbal dalam Sistem Jaringan Komputer (1st ed.). Yogyakarta: Penerbit Deepublish.

Peterson, M. O. (2016). Schemes for integrating text and image in the science textbook: Effects on comprehension and situational interest. International Journal of Environmental and Science Education, 11(6), 1365-1385. https://doi.org/10.12973/ijese.2016.352a

Wang, J., \& Mendori, T. (2015). The Reliability and Validity of Felder-Silverman Index of Learning Styles in Mandarin Version. Information Engineering Express. International Institute of Applied Informatics, 1(3), 1-8. 